\title{
İKİ ADAM BİR KURAM: HAAS ve SCHMITTER İLE NEOFONKSIYYONALIZMIN KARAYİPLER TOPLULUĞU'NA YANSIMASI
}

\author{
TWO-MAN ONE THEORY: THE REFLECTION OF NEOFUNCTIONALISM WITH \\ HAAS AND SCHMITTER TO THE CARICOM
}

\author{
Fulya KÖKSOY*
}

\begin{abstract}
Öz
Supranasyonel ve hükümetlerlerarası özellikleri içinde taşıyarak nev-i şahsına münhasır bir yapr olan Avrupa Birliği’nin, topluluktan birliğe evirilirken geçirdiği dönüşüm sürecinin analizi geçmişten günümüze önem arz etmektedir. Bu noktada, kökeni çok eskiye dayansa da II. Dünya Savaşı sonrasındaki konjontür doğrultusunda somut olarak 1950'lerde Avrupa bütünleşmesine yönelik başlayan sürecin teorik bir zeminde incelenmesi, topluluktan birliğe dönüşen ve içinde birbiriyle etkileşim içinde olan farkl niteliklere sahip bir yapının geçirdiği değişim sürecinin gözler önüne serilmesine yol açmaktadır. Ekonomik bütünleşmeden, siyasi bütünleşmeye evirilme hedefiyle yola çıkan, son dönemde tüm Avrupa'yı etkileyen çeşitli problemler yaşayan, henüz siyasi bütünleşme hedefine ulaşamayan ve yakın gelecekte bu hedefi gerçekleştirme olasılığı bulunmayan Birliğin kuruluşunda ve derinleşme döneminin ortaları (1950 ve 1960'lar) boyunca neofonksiyonalizm kuramının etkin olduğu bilinen bir realitedir. Bu minvalden hareketle çalışmada Avrupa bütünleşmesinde önem arz eden neofonksiyonalizm kuramı, kuramın iki önemli teorisyeninin varsayımları ekseninde analiz edilip, akabinde kuramın Avrupa dışındaki bir bölgede bulunan Karayipler Topluluğu (Caricom) $)^{1}$ üzerindeki işlerliği test edilecektir.
\end{abstract}

Anahtar Kelimler: Neofonksiyonalizm, Avrupa Bütünleşmesi, Ernst. B. Haas, Philippe Schmitter, Karayipler Topluluğu

\section{Abstract}

The analysis of the transformation process of the European Union evolving from Community to Union, which is a sui-generis structure with its supranational and intergovernmental characteristics, is important from past to present. In this point, although its origin is very old, examining the process of European integration, that began in the 1950s in line with the conjuncture after Second World War, on a theoretical basis leads to come to light to the process of change of a structure which is transforming from community to unity and where the different qualities interacting with each other. It is a well-known reality that neofunctionalism theory has been effective in the establishment and mid-deepening period (1950s and 19600s) of the Union which has set out with the aim of evolving from economic

\footnotetext{
Makale Gönderim Tarihi: 06.12.2019

Makale Kabul Tarihi: 25.12.2019

* Dr. Ögr. Üyesi, Batman Üniversitesi, İ.İ.B.F. Uluslararası İlişkiler A.B.D., fulya.koksoy@batman.edu.tr, ORCID: 0000-0001-2345-6789

${ }^{1}$ Çalışmada Karayipler Topluluğu'nun kısaltması olan Caricom kullanılmaktadır.
} 
integration to political integration, has recently experienced various problems affecting the whole of Europe, has not yet reached the goal of political integration and is not likely to realize this objective in the near future. From this point of view, the theory of neofunctionalism, which is important in the European integration, will be analyzed especially through the light of the assumptions of two important theorists of it and then the functioning of the theory will be tested on the Caribbean Community which takes part in a region outside of Europe.

Keywords: Neofunctionalism, European Integration, Ernst B. Haas, Philippe Schmitter, Caricom

\section{GİRIŞ}

Tarihsel bir perspektiften Avrupa'yı ortak bir çatı altında bütünleştirme fikrinin kökensel olarak ortaya çıkışı Eski Yunan'a dayansa da fikirsel bazda söz konusu bütünleşmenin daha somut olarak ifade edilmeye başlaması, Orta Çağ dönemine uzanmaktadır. Ne var ki 19. yüzyıla ${ }^{2}$ gelinceye dek "Birleşik Bir Avrupa'nın” yaratılmasına dönük görüşler reel olarak hayata geçirilememiştir. Bu bağlamda, 19. ve özellikle 20. yüzyıla kadar birleşik bir Avrupa'nın oluşturulmasında salt düşünsel ama söz konusu dönemlerde atılan adımları etkileyecek fikirlerin ortaya konduğu bir süreç yaşanmıştır. Öte yandan, II. Dünya Savaş1 Avrupa bütünleşmesi fikrinin somutlaşmasında önemli bir dönüm noktasını teşkil etmiştir. Öyle ki savaşın Avrupa coğrafyasında sosyal, ekonomik, askeri, siyasi ve psikolojik kırılmalara ve yıkıma neden olması ve siyasi, ekonomik ve güvenlikle ilişkili çıkarları bağlamında Avrupa bütünleşme projesinin yaratılmasında büyük rolü ve desteği olan ABD'nin uygulamaya koyduğu mekanizmalar -Marshall Planı, Truman Doktrini, NATO'nun kurulması- çerçevesinde Batı Avrupa devletleri arasında işbirliği ortamı tesis edilmiş ve Avrupa bütünleşmesine hız kazandırılmıştır. 1950'lerde Fransız Dışişleri Bakanı Robert Schuman ve siyasetçi Jean Monnet'in hazırladığı savaş sanayisinin iki önemli hammaddesi ve Fransa ve Almanya'nın sanayilerinin temeli olan kömür ve çelik üretimin üst bir otorite altında yönetilmesi bağlamında uluslarüstü bir yapının öngörüldüğü Schuman Bildirisi akabinde Paris Antlaşması ile Avrupa Kömür Çelik Topluluğu'nun (AKÇT) ve Roma Antlaşması ile Avrupa Ekonomik Topluluğu (AET) ve Avrupa Atom Enerjisi Topluluğu'nun (AAET) kurulması, bütünleşme yolunda atılan önemli adımları teşkil etmektedir. Maastricht Antlaşması (Avrupa Birliği Antlaşması-ABA) ile topluluktan birliğe evrilen yapı içerisinde ise ekonomik bütünleşmeyi giderek dış politika, adalet ve iç işleri, güvenlik gibi alanlarda siyasi entegrasyona doğru eklemleme çabaları geçmişten günümüze devam etmektedir.

\footnotetext{
2 13. yüzyıldan 19. yüzyıla kadar birleşik bir Avrupa'nın yaratılmasına ilişkin çeşitli fikirler ortaya konmuştur. Bu bağlamda, Dante 1310 yılında yazmış olduğu "Monarchia" isimli eserinde Birlik düşüncesine yer verirken aynı dönem Pierre Dubois de Birlik yaratılması düşüncesini önceliklendirmiştir. Öte yandan, William Penn'in 1693 yılında yazdığı “ Avrupa'nın Şimdiki ve Gelecekti Barışı” isimli çalışma ve 1713 yılında Abbe de Saint Pierre'in “ Avrupa'da Kalıcı Barışın Sağlanması İçin Bir Proje” başlıklı çalışması, Hristiyan devletler arasında kurulacak bir üst örgütlenmeye çağrıda bulunmaktadır. Diğer taraftan, Avrupa coğrafyasında oluşturulacak bir uluslarüstü yapının istikrarı sağlayacağını öngören Jean Jacques Rousseau ve ünlü eseri "Edebi Barış" ile Avrupa birleşik devletlerinin kurulmasından bahseden Immanuel Kant, Avrupa bütünleşmesinin fikirsel altyapısı bağlamında önem arz etmektedir. 19. yüzyılla beraber, Avrupa bütünleşmesi fikrinin somut olarak hayata geçirilmesi sürecinde ise daha reel adımların atıldı̆̆ı görülmektedir. Mevzubahis adımlara örnek olarak 1819 yılında Prusya'da ticarete yönelik engellerin kaldırılması ve 1834 yılında Alman Gümrük Birliği’nin hayata geçirilmesi verilebilir.
} 
Görüldüğü gibi Avrupa bütünleşme süreci, muazzam bir dinamizmi ve fikri temelleri bağlamında tarihsel bir derinliği içerisinde barındırmaktadır. Coğrafi, ekonomik ve siyasi bütünleşmenin hedeflendiği mevzubahis bütünleşme girişiminin başlangıç noktasını ise ekonomik bütünleşme aşaması oluşturmaktadır. Bu bağlamda ekonomik bütünleşmeden siyasi bütünleşmeye doğru gidilmesi hedefiyle yola çıkılan Avrupa entegrasyonunun teorik bir zeminde analiz edilmesi önem arz etmektedir. Bu noktada her ne kadar bazı eleştiriler yapılsa da genel kabul gören, 1940'lı yılları etkisi altına alan fonksiyonalizm kuramının temsilcisi David Mitrany’nin çalışmaları üzerine inşa edilen ${ }^{3}$ Neo-Fonksiyonalizmin, Avrupa Birliği'nin varoluşundaki bütünleşme sürecinin analizi ekseninde son derece önemli bir kuramı teşkil etmesidir. Teorinin varsayımına göre ekonomik alanda bütünleşme sağlayan devletler, siyasi bütünleşme aşamasına çok daha kolay bir şekilde evrilebileceklerdir. Bu noktada ekonomik bütünleşmeden siyasi bütünleşmeye geçişin otomatik olarak ${ }^{4}$ gerçekleşeceği vurgulanmaktadır. Nitekim bu varsayım, Schuman Deklarasyonu bağlamında Avrupa Kömür Çelik Topluluğu (AKÇT) ile başlayan Avrupa bütünleşme sürecini doğrular niteliktedir.

Bahsedildiği üzere Avrupa'da siyasi birlik oluşturma çabaları çok eskiye dayanmaktadır. Yakın dönem zarfında bu konuda gerçekleştirilen en önemli adım ise Fransız Dışişleri Bakanı Robert Schuman'ın Deklarasyonu ve sonrasındaki girişimlerdir. Öyle ki Schuman'ın uluslarüstü bir yapıyı öngörmesi ve siyasi birliğe evrilmeyi amaçlaması önem arz etmektedir. Ernst B. Haas, Schuman Deklarasyonu'nda ortaya konan bu iki amacı neofonksiyonalizm adı altında teorik bir yapıya entegre etmiştir. Bu bağlamda, Ernst B. Haas'ın Avrupa bütünleşmesi içinde geliştirilen neofonksiyonalizmin kurucu babası olması abartılı bir ifade değildir (Rosamond, 2005:238). Öte yandan Leon Lindberg, Lawrance Scheineman ve Amitai Etzioni gibi kuramın etkin teorisyenlerinden biri olan Philippe Schmitter'ın teoriye göz ardı edilemeyecek katkıları bulunmaktadır. Bu noktada Ernst B. Haas ve Philippe Schmitter'ın kuramın geliştirilmesine dönük yapmış oldukları katkı ve sunmuş oldukları bakış açıları ele alınırken karşılaştırmalı bir profil oluşturma yöntemine başvurulmakta ve Haas ile ilgili "tam anlamıyla teknokrat Avrupa yanlısıdır ve Avrupa federalizmine tamamen karşıdır” görüşünün de esas olarak söz konusu olmadığı gösterilmeye çalışılmaktadır.

$\mathrm{Bu}$ çalışmanın temel amacı, "aslında temel hedefinin Avrupa Entegrasyon teorisi yaratmak değil, bütünleşme dinamikleri hakkında çok üretken bir portfolyoya ulaşmak" (Rosamond, 2005: 243) olduğunu belirten ve Avrupa bütünleşmesini en iyi açıklayan Neofonksiyonalist kuramın fikir babası olarak kabul edilen Ernst B. Haas ve yine teoriye önemli katkılarda bulunan Philippe Schmitter'ın neofonksiyonalist kurama ilişkin bakış açılarını, katkılarını ve bir bütün olarak teorinin temel çıktılarını analiz ederek, söz konusu kuramın Avrupa dışındaki bir diğer topluluğa -Karayipler Topluluğu (Caricom)- uygulanıp uygulanamayacağı sorusuna cevap aramaktır. Topyekün olarak Avrupa entegrasyon teorileri, AB dişındaki diğer birliklerin analizinde uygun bir seçimi yansıtmaktadır. Neofonksiyonalizm ise Avrupa

\footnotetext{
3 Neofonksiyonalizm salt fonksiyonalizm teorisi üzerine tesis edilmeyip, içerisinde transaksiyonalizm ve federalizmin de izlerini taşımaktadır. Bu noktada, neofonksiyonalizmin amalgam bir kuram olduğu görülmektedir. Ancak, söz konusu teorinin fonksiyonalizmin üzerine kurulduğuna yönelik genel bir görüş bulunmaktadir.

${ }^{4}$ Ekonomik bütünleşmeden siyasi bütünleşmeye geçişin yayılma etkisiyle (spill-over) otomatik ve tek yönlü olarak gerçekleşeceği savı zaman içerisinde terk edilmektedir. Bu noktada, ulusalcılığın entegrasyon süreci üzerinde ve ulusal hükümetlerin supranasyonel aktörler üzerindeki sınırlayıcı etkisi kabullenilmektedir (Haas, 1975).
} 
bütünleşmesinin başlangıç aşaması noktasını ortaya koymaktadır. $\mathrm{Bu}$ minvalden hareketle, neofonsiyonalizm kuramının Coricom'a yansitılarak söz konusu topluluğun bütünleşme sürecinin mevzubahis teori çerçevesinde test edilmesi amaçlanmaktadır. Ancak bu noktada belirtilmesi gereken önemli bir diğer husus ise söz konusu kuramın ve teorisyenlerin ortaya koyduğu tüm varsayımların Caricom ile tamamen örtüşmesine yönelik bir beklentinin olmamasıdır. Nitekim nev-i şahsına münhasır bir birliğin kuruluş deneyimini en iyi şekilde açıklayan bir teorinin özellikle Avrupa dışı bir coğrafyada kurulmuş olan bir topluluğa tam anlamıyla genellenmesi büyük zorlukları içermektedir. Yine de mevzubahis teorinin ilgili varsayımlarını Caricom'a yansıtarak, neofonksiyonalizm-Avrupa Bütünleşmesi ve Caricom bütünleşmesi ekseninde ortaya çıkacak bir denklemin analiz edilmesi hedefi söz konusu olmaktadir.

\section{NEOFONKSIYYONALIZM VE AVRUPA BÜTÜNLEŞMESİ}

Tarihsel kökeni Eski Yunan’a kadar götürülebilen Avrupa bütünleşmesine yönelik fikir ve adımların, 20. yüzyılla beraber somut bir zemine oturarak kurumsal bir nitelik kazandığ görülmektedir. Bütünleşme veya entegrasyon "siyasi aktörlerin bağlılıklarını, beklentilerini, sadakatlerini ve eylemlerini ulus devletler üzerinde yetkiye sahip yeni bir merkeze kaydırma süreci” olarak tanımlanırken (Haas, 1958:16) benzer bir diğer tanımda entegrasyon, “ devletlerin birbirlerinden bağımsız olarak dış ve ulusal politikalarını yürütme isteği ve yeteneğinden vazgeçmeleri, bunun yerine ortak kararlar almayı ve karar alma sürecini yeni merkezi organlara delege etmeyi tercih ettikleri bir süreç" şeklinde ifade bulmaktadır (Lindberg, 1963:6). Bir başka tanımda ise bütünleşme, "farklı devletlerden oluşan bir kurumun, zorlama araçlarını kullanma yetkisini ele geçirmesi, karar verme mekanizmasına sahip olması ve söz konusu devletlerin vatandaşları için bir kimlik oluşturabilmesi süreci” olarak ortaya konmaktadır (Etzionai, 1962:45). Bu tanımlamalardan hareketle, içerisinde II. Dünya Savaşı'nın yarattığı tahribatların bir daha yaşanmamasına dönük idealist, Almanya'nın yeniden güçlenme olasılığının devletlerin yetki devrettikleri bir üst mekanizma içinde eritilmesi bağlamında pragmatik (Açıkmeşe, 2004:2) hedefleri barındıran Avrupa bütünleşmesi, Almanya ve Fransa arasında yaşanan sorunlara mutlak çözüm sağlanmasına dönük siyasi, Sovyet tehdidinin bertaraf edilmesine ilişkin askeri, refahın sağlanmasına yönelik ekonomik olan sacayağına dayanmakta ve bütünleşmenin hayata geçmesinde büyük rolü olan bir diş gücün -ABD- etkisi ve desteğiyle hayata geçmiş bulunmaktadır. Bir bütün olarak "bütünleşme/entegrasyon" kavramı analiz edilirken devletlerin niçin bu entegrasyona yöneldikleri ve neden ulusal egemenliklerini kendilerinin üzerinde bir topluluğa devretme gerekliliği içine girdikleri sorularına yoğunlaşılmaktadır. Bu soruların Avrupa düzlemindeki cevabının teorik bir zeminde ele alınmasında ise 1950'lerde başlayıp 1960'larda derinleşen Avrupa bütünleşmesinin analizinde önem arz eden Neofonksiyonalizm kuramı devreye girmektedir. Nitekim söz konusu teori, Avrupa entegrasyon sürecine ve bu sürecin siyasi bir aşamaya evrileceğine yönelik varsayımlarda bulunmaktadır. Öncelikle Avrupa Kömür Çelik Topluluğu (AKÇT) üzerine yoğunlaşan teori, akabinde Avrupa Ekonomik Topluluğu (AET) ve Avrupa Atom Enerjisi Topluluğu (AAET) düzleminde yaşanan "uluslarüstü” entegrasyon sürecine odaklanmaktadır. Öte yandan, 1960'lı yılların sonuyla beraber durgunluk dönemine 
giren Avrupa bütünleşme süreci bağlamında kuram, kendine öz eleştiri oklarını yönelterek revize edilmeye çalışılsa da 1970'lerin sonlarıyla beraber güncelliğini kaybetmeye başlamıştır. Ancak bu duruma rağmen neofonksiyonalizm kuramı, Avrupa bütünleşmesinin tarihsel gelişimi ekseninde ortaya çıkan ilk ve bir topluluğun birliğe dönüşüm deneyimini en iyi şekilde ortaya koyan teori olması bağlamında önem arz etmektedir.

Neofonksiyonalizm kuramının varsayımlarının doğrulandığı ve Avrupa Entegrasyon sürecinin hız kazandığı 1950'lerin sonu ve 1960'lı yılların ortaları arasında geçen dönem, söz konusu teorinin altın çağını teşkil etmektedir. Mevzubahis teori doğrultusunda çeşitli varsayımların ortaya konduğu görülmektedir. Bu bağlamda, genel bir çerçevede neofonksiyonalizm kuramının varsayımlarını analiz etmek gerekirse teorinin şu özellikleriyle karşılaşılmaktadır:

1-Entegrasyon bir durum değil, bir süreç olarak anlaşılmaktadır. Süreç olgusu ise bütünleşme sürecinin zamanla ve kendi dinamikleri ile geliştiği varsayımına işaret etmektedir.

2-Entegrasyon çok yönlü, farklı ve çeşitli aktörler (özellikle ulusal hükümetler üzerinde yer alan supranasyonel aktörler) tarafindan karakterize edilmektedir (Bergmann ve Niemann, 2013:4-5)

3-Kararlar, işbirliğine dayanan karar alma süreçlerinde kendi deneyimlerinden öğrenme ve tercihlerini değiştirme kapasitesine sahip rasyonel ve kendi-çıkarlarına dayanan aktörler tarafindan alınmaktadır (Haas, 1958:291; Haas, 1970:627).

4-Topluluğun oluşumunda ortak çıkarlarda uzlaşıdan/uyumdan yana olan katılımcıların/aktörlerin yer aldığı supranasyonel düzlemde karar verme, karşılıklı etkileşimin önemli bir formunu teşkil etmektedir (Haas, 1964:66).

5- Kuramin teorisyenleri, teori ekseninde temel hedeflerden birinin de Avrupa entegrasyonu deneyimini diğer bölgelere/çevrelere genişletmek olduğunu belirtmektedir (Barrera ve Haas, 1969, Haas, 1961; Haas ve Schmitter, 1964; Rosamond, 2005).

Söz konusu özelliklerine ek olarak, Neofonksiyonalizmin odak noktası ekonomik ve siyasi entegrasyon arasındaki denklemdir (Eilstrupp-Sangiovanni, 2006:89). Bu noktada, teknik baskıların sektörler arasında yayılma etkisi yaratacağı ve entegrasyonun faydasını görüp, devam etmesini isteyen devlet-dışı aktörlerin (süreçte aktif katılan sosyal aktörlerin), süreçteki değişim ve işlemlerin etkisi doğrultusunda siyasi bir sürece evrileceği varsayılmaktadır. Ayrıca, entegrasyon sürecini salt siyasileştirmeyip aynı zamanda kurumsallaştıran Neofonksiyonalizm kuramı ekseninde siyasi aktörlerin ulusal çözümlere kıyasla uluslarüstü/supranasyonel çözümleri kendi öz-çıkarları bağlamında daha faydalı olarak görmeleri ve bu alg1 çerçevesinde söz konusu aktörlerin sürece aktif olarak katılarak bir öğrenme sürecinin oluşması önem arz etmektedir (Kahraman, 2014:73-74).

Entegrasyon süreci bağlamında ulusal hükümetlerin ilk adımı attıktan sonra sürecin söz konusu aktörlerin istekleri ve beklentilerinin daha ötesine geçmesi durumu, kuram çerçevesinde yayılma (spill-over) etkisiyle analiz edilmektedir ki bu noktada Jeppe TranholmMikkelsen tarafindan ortaya konan fonksiyonel (sektörel) -functional-, siyasi -political-ve işlenmiş -cultivated- olmak üzere üç tür ${ }^{5}$ yayılmadan bahsedilmektedir (Kahraman, 2014:76;

\footnotetext{
${ }^{5}$ Bu üç çeşit yayılma etkisine ek olarak 1997 yılında Christopher Preston'ın ortaya koyduğu "coğrafi yayılma" etkisi de bulunmaktadır. Avrupa düzleminde söz konusu kavram, Birlik politikalarının çevre (komşu) devletlere
} 
Tranholm-Mikkelesen, 1991:1-21). Birbiriyle bağlantılı ve iç içe geçmiş, birbirlerinden izole edilemeyen sektörlerden oluşan modern ekonomilerde, bir sektörde meydana gelen olumlu ve/veya olumsuz gelişmelerin bir diğeri üzerinde etki yaratmasını ortaya koyan fonksiyonel yayılmada, bir sektörde alınan entegrasyon kararının diğer sektörlere doğru yayılması ele alınmaktadır (Lindberg, 1963:10; Haas, 1958:297, 383; Bergmann ve Niemann, 2013:5; Kahraman, 2014:76). Avrupa Kömür Çelik Topluluğu ile başlayan Avrupa Entegrasyon deneyiminin Avrupa Ekonomik Topluluğu ve Avrupa Atom Enerjisi Topluluğuna evrilmesi veya tek pazardan adalet ve iç işleri alanına doğru yayılması fonksiyonel yayılmanın Avrupa düzleminde kanıtlanmasına dönük örnekleri teşkil etmektedir. Bununla beraber, ulusaltı ve uluslarüstü alanda ortaya çıkan siyasi yayılmada entegrasyondan fayda sağlayan siyasi elitler ve çıkar gruplarının isteklerini, beklentilerini, faaliyetlerini ve bağlılıklarını ulusal düzlemden uluslarüstü düzleme aktararak bir öğrenme süreci ekseninde ulusal seviyedeki çözümlere kıyasla uluslarüstü çözümlere yönelmelerinin ve bütünleşmede kolaylaştırıcı rol oynayan ve ortak çıkarları ön plana koyan supranasyonel kurumların altı çizilmektedir (Niemann, 2016:45; Haas, 1958:283-350). İşlenmiş yayılmada ise supranasyonel kurumların ${ }^{6}$ entegrasyonun hızlanmasında takip ettikleri bütünleştirici girişimler, karar alma sürecindeki etkileri ve hem çıkar grupları hem de siyasi elitlerle giriştikleri işbirliği ön plana çıkmaktadır (Niemann, 2016:5). Birlik içinde tarife dışı ticaret engellerinin kaldırılmasına dönük iç pazarın tesisi için 1985 yılında Komisyon tarafından yayınlanan Beyaz Kitap sonrasında Avrupa Tek Senedi üzerinde anlaşılması ve söz konusu senedin 1987 yılında yürürlüğe girmesi ise işlenmiş yayılma için verilebilecek bir örneği oluşturmaktadır.

Neofonksiyonalistler bağlamında ele alınması gereken bir diğer husus da başlangıçta siyasallaşma -politicisation- sürecine yeterince önem verilmezken 1960'ların sonları itibariyle söz konusu kavrama ve bu bağlamda kamuoyunun rolüne daha fazla dikkat çekilmeye başlamasıdır (Niemann, Lefkofridi ve Schmitter, 2018:6). Ekonomik ve siyasi entegrasyon arasında müdahale edici bir değişken olarak görülen siyasallaşma (Haas ve Schmitter, 1964:707), "ortak karar alma konusundaki tartışmaların arttı̆̆ı bir süreç" olarak ifade edilmektedir (Schmitter, 1969:166). Öte yandan, kurumsal adaptasyonun sağlanması ve diş etkilerden korunmak için strateji oluşturulması (Faber, 2010) gerekliliğini vurgulayan "Doğal Entropi" -Natural Entropy- hipotezi, kuram çerçevesinde ortaya konmaktadır. Söz konusu hipotez ekseninde adaptasyonun ve dışsal durumların etkisinin ön planda olduğu görülmektedir.

Sonuç olarak, Neofonksiyonalizm kuramı ve Avrupa Bütünleşmesi üzerine yoğunlaşılan bu bölüm akabinde mevzubahis teorinin önemli teorisyenlerinin ortaya koyduğu çıtılarla genelden özele bir analiz yapılması amaçlanmaktadır. Bu bağlamda teorinin kurucusu olarak kabul gören Ernst B. Haas ve bir diğer önemli teorisyen Philippe Schmitter'ın varsayımları ekseninde neofonksiyonalizm teorisi daha detaylı bir şekilde ele alınmaktadır.

yayılmasına ve başarılı olarak değerlendirilen Avrupa entegrasyon sürecine diğer devletlerin katılım sağlamaya yönelik istekliliklerine işaret etmektedir (Berran'dan akt, Mercan, 2011:71).

${ }^{6}$ Her ne kadar Ernst Haas, salt Yüksek Otorite ve Avrupa Komisyonuna vurgu yaparken, daha sonra teori ekseninde daha genel bir perspektifle tüm supranasyonel kurumların rolü üzerinde durulmaktadır. 


\subsection{Ernst B. Haas ve Neofonksiyonalizm}

Neofonksiyonalizmin kurucu babası olarak kabul edilen Ernst Haas'1n, Avrupa bütünleşmesi üzerine çalışmalar yaptığı görülmektedir. Haas, amacının Avrupalı, Amerikalı, ulusal, uluslararası veya refah devleti değerlerine göre Birleşik bir Avrupa'nın erdem ve eksikliklerini değerlendirmek olmadığını belirtmiştir (Haas, 1958:xi). Bu noktada Haas'ın amacı, bütünleşmenin doğası hakkındaki savları elde etmek için entegrasyon sürecini parçalara ayırarak incelemek olmuştur (Mason, 1959:173). Bu bağlamda, Haas'ın analizi seçilmiş gruplar, kurumlar ve ideolojiler üzerine odaklanmıştır (Haas, 1958:xii). Öte yandan, ulusal düzeyin üzerinde yeni bir alan yaratma konusundaki tepkileri ölçmek için siyasi aktörlerin (siyasi partiler, Avrupa Kömür Çelik Topluluğu çalışanları, sendikacılar, sanayiciler) tutum ve davranışlarını incelemiştir (Mason, 1959:174). Bununla beraber, doktora tezini AKÇT üzerine yazan Haas'ın neden bu konu üzerine yoğunlaştığını hiç bir zaman belirtmediği ifade edilse de (Schmitter, 2005:256) bütünleşme sürecini icra etmek konusunda söz konusu kurumun yeterli güç ve işlevlere sahip olmasından dolayı bu kurum üzerine yoğunlaştığ1 vurgulanmaktadır (Mason, 1959:173; Haas, 1958:xii). Diğer taraftan, Avrupa bütünleşme süreci dinamiklerini açıklama noktasında bilinen en yetkin teorisyen olmasına rağmen, ünlü eseri "The Uniting of Europe" dışında Neofonksiyonalizme ilişkin çok daha etkili bir katkı sağlamadığı da ifade edilmektedir (Schmitter, 2005:255).

Haas, Neofonksiyonalizmin Uluslararası İlişkiler disiplinin hakim teorilerine yönelik bir alternatif olduğunu belirtmiştir (Rosamond, 2005:239). Aslında söz konusu teori, liberal paradigmaya yaslanmaktadır. Ancak buna rağmen uluslararası sistemde barış ve uzlaşının tesisini sınırlı bir çerçevede öngörmektedir. Bununla beraber Haas, Avrupa'ya ihtiyacı olan düzenlemelerin yapılabilmesi için önceliklerin olduğunu ve söz konusu önceliklerin uyumlaştırılmasının gerekliliğini vurgulaması çerçevesinde sıra dişı bir argüman ortaya koymaktadir.

Eklektik bir yaklaşım ortaya koyan Haas, Neofonksiyonalizmi David Mitrany'nin fonksiyonalizmi ve AKÇT'na giden yolda önemli bir kişi olan Jean Monnet'nin stratejileri üzerine inşa etmiştir (Schmitter, 2005:256). Neofonksiyonalizm, siyasi birlik oluşturma amacının sağlam bir temele oturması için çok daha hassas ve kırılgan olan siyasi alandan başlamak yerine ekonomik bütünleşmeden başlayarak Avrupa entegrasyonunun uluslarüstü bir örgütün altında sağlanması gerektiğini belirtmektedir. Ayrıca söz konusu teori, Jean Monnet ve Robert Schuman'ın görüşlerini yansıtması açısından da önem arz etmektedir. Sonuç olarak, Avrupa bütünleşmesinin teorik bir zemine oturtulması noktasında Neofonksiyonalizm, (Özen, 1998:1-4) çok önemli bir başlangıç aşamasını temsil etmektedir. Başarılı bir bütünleşmenin analizinde çeşitli gösterge ve ölçümler önemli bir rol oynamaktadır. Söz konusu göstergeler; bölge içi etkileşimlerin artması, ortak bir uzlaşı ekseninde aktörlerin sürece uyum göstermesi, bağl1lık ve beklentilerin uluslarüstü bir alana aktarılması ve söz konusu uluslarüstü alanın geniş ölçüde kabul görmesidir (Mattli, 2005:329). Haas, bütünleşme için gerekli koşulları 1) çoğulcu sosyal yapı, 2) yeterli seviyede ekonomik ve endüstriyel gelişimin sağlanması 3) katılımcılar arasında ortak ideolojik yaklaşımların oluşması 4) parlementer demokrasi olarak belirtmiştir (Haas, 1958:143). Öte yandan, bütünleşmenin ilerleyen aşamasında yeni bir siyasi topluluk oluşacağından bahseden Haas, bu siyasi toplumun federal bir devlet oluşumuna evrileceği beklentisinde olmadığını 
ifade etmiştir. Ancak bu durumu, bütünleşmenin son aşamasında gerçekleşebilecek bir olasılık olarak da ifade etmesi (Haas, 1958:7), Haas'ın federalizme ihtiyatlı olduğunu fakat tamamen karşıt olmadığını göstermektedir.

Avrupa bütünleşmesi açısından Haas tarafından David Mitrany’nin “dallanma” (ramification) kavramının bir adım daha ileri seviyeye taşınıp "yayılma etkisininin" (spill-over effect) geliştirilmesi, (Arı, 2010:444) Avrupa Entegrasyonu'nun daha somut bir çerçevede algılanması açısından önem arz etmektedir. Ancak Haas tarafindan geliştirilen bu kavram, içeriksel bir açıklamaya sahip olmaması noktasında eleştiriye uğramaktadır (Schmitter, 2005:258).

Haas iki çeşit yayılma'dan bahsetmektedir. Bu noktada, “ekonomi'nin (veya toplum) belirli sektörlerindeki işbirliği, bitişik sektörler için teknokratik bir baskı yaratmaktadır" hususunu ifade eden ilk çeşit, fonksiyonel yayılma (functional spill over) iken; ikinci çeşit ise politik yayılma'dır (political spill over). Bu ise, bazı alanlarda devam eden işbirliği, diğer alanlarda resmi olmayan müteşebbisler olarak hareket etmeleri için uluslarüstü yapılara yetki verildiği zaman oluşmaktadır (Moravcsik, 2005:352). Ekonomik entegrasyondan siyasi entegrasyona doğru yol alacak yapı çerçevesinde siyasi bütünleşme, Haas tarafından şu şekilde ifade edilmektedir: "Siyasi bütünleşme süreci, farklı bölgelerdeki politik aktörlerin bağl1lıklarını, beklentilerini yeni bir merkeze kaydırma sürecidir. Bu yeni merkezin kurumları, yasama gücünü önceki ulus devletlerin üstüne taşımaktadır. Sonuç olarak, önceden var olanların üzerinde yeni bir siyasi toplum oluşacaktır" (Haas, 1958:16). Bununla beraber, ekonomik entegrasyonun siyasi nedenlere dayanabileceği gibi siyasi sonuçlara da yol açabileceği ifade edilmektedir. Eğer kömür ve çelik gibi belirli bir alanda veya bir bütün olarak ekonomideki bir bütünleşme, merkezi karar alma alanının etkisinin artmasıyla aynı doğrultuda ilerliyorsa, bu durum siyasi işbirliğinin ve siyasi toplumun da büyümesine neden olmaktadır (Haas, 1958:12-13). Öte yandan, bağlılık/sadakat kavramının Haas'ın çalışmalarında önem arz ettiği görülmektedir. Bu noktada Haas siyasi toplumu, özel gruplar ve bireylerin belirli zaman ve alanlarda herhangi bir diğer siyasi otoritedense onların merkezi siyasi kurumlarına daha fazla sadakat gösteren grup olarak tanımlamaktadır (Haas, 1958:5).

Neofonksiyonalist teoride bütünleşmenin amacı, yeni bir siyasi toplum yaratmaktır. Bir başka ifadeyle, bütünleşme sonucunda siyasi topluma ulaşmak hedeflenmektedir. Nitekim burdaki hedef yeni, geniş ve bölgesel olarak örgütlenen siyasi bir toplumun oluşmasıdır. $\mathrm{Bu}$ bağlamda, bütünleşme ilk olarak teknik ve ekonomik sektörde başlayıp ekonomik anlamda refah sağlandıktan sonra yayılma etkisiyle otomatik olarak (Moravcsick, 2005:353) siyasi sektöre kayacaktır (Özen, 1998:41-42; Gehrels, 1960:196).

Ekonomik entegrasyondan siyasi entegrasyona geçiş aşamasında gerekli koşulları araştıran Haas, bu süreçte çeşitli zamanlarda etkin olan üç farklı değişken olduğunu ifade etmiştir. Bu değişkenlerden ilkinde, üye devletlerin büyüklüğü, söz konusu devletlerin ilişkileri ve ulusal elitlerin bütünleyiciliği ele alınırken; ikinci değişkende hükümetlerin benzer hedefleri ile bölgesel organlara verilen gücün derecesi belirtilmektedir. Son değişkende ise, bölgesel problemlere dair kararların işbirliği ile alınması, bölgelerde iletişim ve etkileşimin olması ve bölgedeki ulusal hükümetin sorunların çözümünde etkin olması olarak belirlenen ve bütünleşmenin somut olarak ortaya konulmasını sağlayan özellikler bulunmaktadır (Canbolat'tan akt. Yapıc1, 2007:144). 
Kurumsal çerçevede sağlanacak işbirliği ve etkileşimin gerekliliğinin, kurumların sağlıklı işleyişi için bir ön koşulu oluşturduğu, Neofonsiyonel teorinin önemli bir varsayımını teşkil etmektedir. Bir başka ifadeyle fonksiyonların iyi bir şekilde icra edilmesi için farklı çıkarların uyumlaştırılması gerekliliği teorinin ana iddiasıdır. Haas'ın teorisi bir bölgesel bütünleşme teorisidir. Önce bölgeler, sonra uluslar ve daha sonra supranasyonalliğe gidilebileceği ifade edilmektedir. Bölgeselcilik bağlamında 1) yerel yönetimlere vurgu yaparak, söz konusu yerel yönetimler arasında sağlanacak işbirliği ile tabandan bütünleşmeyi sağlamak 2) bölgeler ile Avrupa kurumları arasında iletişim ve etkinliği arttırma yoluyla bütünleşmeyi sağlamak şeklinde iki hususdan bahsetmektedir. Yeni işbirliği alanları ve bu alanların devamlılığ ise 1) bölgeler 2) uluslar 3) Avrupa'da bulunan değişik firmalar arasında gerçekleştirilen hamlelerle yayılarak sağlanacaktır. Ancak Haas teknik ve ekonomiyle sınırlanan bir Avrupa düşünmemektedir.

Ernst Haas ve Neofonksiyonalizm ile ilişkili tüm bu analizlerle beraber, Haas'ın kendi teorisine yönelik ilgisini kaybetmesi ise bir ironiyi oluşturmaktadır. Haas'ın kendi teorisine yönelik ilgisini kaybetmesi ise, 1970'li yıllarda Avrupa'da entegrasyon sürecinin durgun bir şekilde seyir etmesine bağlanmaktadır. Öte yandan, C. De Gauelle'in genişlemeyi ve hükümranlığı durdurup mevzubahis entegrasyon sürecini Fransız dış politikasının bir aracı haline getirmesi ekseninde Birleşik Avrupa'nın geleceğinin milliyetçi ve agresif bir yapıya dönüşeceği ihtimali Haas'1 endişelendirmiştir. Bu noktada Haas'1n, nicelik olarak bütünleşme sağlansa dahi nitelik olarak sağlanamayacağınından yola çıkarak farklı konularda çalışmalara yöneldiği belirtilmektedir. Son tahlilde, Neofonksiyonalizm teorisi ve teorinin kurucu babası Ernst Haas'ın Avrupa bütünleşmesi açısından önemli olduğu ve olmaya devam edeceği vurgulanmaktadır (Schmitter, 2005:264-265).

\subsection{Philippe Schmitter ve Neofonksiyonalizm}

Neofonsiyonalist teorisyenlerden biri olan Philippe Schmitter'ın, teoriye önemli katkılarda bulunduğu görülmektedir. Nitekim, Haas tarafından geliştirilen yayılma etkisi Schmitter tarafından aktör bütünleşme stratejilerinden biri olarak değerlendirilmektedir. Ayrıca söz konusu yayılma etkisi kümülatif bir eğilime sahiptir. Öyle ki siyasi alanlarda ve ortak karar alma düzeylerinde çok daha fazla ulusal aktörün yer alması bu eğilimi açıklamaktadır (Schmitter, 1969:165-166). Schmitter, dinamik bir bütünleşme sürecinin aktör stratejilerine dayandığını ifade etmektedir. Öte yandan Schmitter'a göre her ne kadar yayılma etkisi (spill over) siyasi bir topluluğun ortaya çıkmasında önemli bir strateji olsa da aktör stratejileri diğer seçeneklerle birlikte yayılmanın karışmasıyla oluşmaktadır (Rosamond'dan akt. Yapıcı, 2007:144). Mevzubahis aktör stratejileri Schmitter tarafından şu şekilde ortaya konmaktadır:

- Spill-Over: Hem fonksiyonların/sadakatin/bağl1lıkların alanı hem de düzeyinin artması anlamina gelmektedir.

- Spill-Around: Sadece fonksiyonların alanının artması ancak otoritenin düzeyinin sabit kalması anlamına gelmektedir.

- Build-Up: Ortak kurumların kapasitesi ve karar verme otonomisinde artış fakat onların yeni sorunsal alanlara girişinin kabul edilmeyişi anlamına gelmektedir.

- Retrench: Ortak dayanışma düzeyinin artması, fakat kurumların belirli alanlardan geri çekilmesidir. 
- Muddle-About: Çeşitli sorunlar üzerinde bölgesel bürokratların tartışması, öneride bulunması ve karşı çıkması fakat değerleri tahsis ederken onların gerçek kapasitelerindeki azalmadır.

- Spill-Back: Kurumların hem fonksiyonlarının alanı hem de otoritesinin azalarak bir önceki duruma dönmesidir.

- Encapsulate: Marjinal değişimler tarafindan oluşan krizlere cevap vermektir (Schmitter, 1970:846).

$\mathrm{Bu}$ aktör stratejileri devletler için seçim yapabilecekleri bir tipoloji ortaya koymaktadır. $\mathrm{Bu}$ bağlamda Schmitter'ın yayılma kavramı üzerinde değisşiklik yaptığını görmekteyiz.

Schmitter, bütünleşme teorilerinin varsayımlarından da sıklıkla bahsetmektedir. Bu bağlamda, Avrupa bütünleşme sürecinin karşılıklı anlaşmaya dayandığını, ulusal ve uluslararası hiçbir aktörün fiziksel güce başvurmayacağını, temel problemin de Avrupalı olmayanlar dışında Avrupa'nın nasıl oluşturulacağı olduğunu ve herkese eşit davranılırsa Avrupalı olmayan Avrupalıların kendi benliklerinden Avrupa kimliğini ayırt etmeyeceklerini belirtmiştir (Schmitter, 2005:258).

Öte yandan, Schmitter'in kurama katkı sağlamaya dönük çabaları Neofonksiyonalizmi bir bütünleşme olduğu kadar parçalanma/dağılma teorisi olarak mükemmelleştirmektedir (Rosamond, 2005:249; Schmitter ve Letkofridi, 2016). Bu noktada Schmitter, son dönemlerde neofonksiyonalizm'in orijinal görüntüsü içinde parçalanma sonuçlarının açıklanmasının onun benzersiz bir özelliği olduğunu vurgulamaktadır (Schmitter, 2004:47). Ona göre, neofonksiyonalizm diğer bütünleşme teorilerine bir alternatif olmaktansa oldukça kompleks bir süreci açıklamaya çalışan bir teoridir (Schmitter, 2004:69). Diğer taraftan Schmitter, dişsal faktörler hipotezini ortaya koymakta ve söz konusu dışsal durumlar bağımsız değişkenler olarak ifade edilmektedir. Bölgesel entegrasyon sürecinde dışsal faktörlerin etkisine işaret eden söz konusu hipotez bağlamında Schmitter, ulusal yapı ve değerlerdeki değişikliklerin öngörülebileceğini ancak devletlerin küresel konumları ve statülerinin dışsal faktörlerle belirlenmeye devam edeceğini ortaya koymaktadır. Ayrıca istisnai dışsal faktörler oluşmadıkça, tüm entegrasyon süreçlerinin bir durgunluk dönemi yaşayacağ vurgulanmaktadır (Schmitter, 2002:21-22; Schmitter ve Letkofridi, 2016:21). Ek olarak dişsallaşma hipotezi, devletlerin (topluluğa ve/veya birliğe üye devletlerin) ortak müzakerelerini küresel bağlamdan izole etme teşebbüslerinin büyük zorluklara yol açacağını ortaya koymaktadır (Schmitter, 2002:9).

Schmitter, Neofonksiyonalizmi açıklarken Haas'ın söz konusu açıklamayı “Beyond The Nation State" isimli çalışmasının giriş kısmında oldukça detaylandırması sebebiyle geniş kapsamlı bir açıklamaya gerek olmadığını ancak kuramın dikkat çekici özelliklerinin belirtilmesi gerektiğini vurgulamıştır (Schmitter, 2005:258). Bu özellikler şunlardır:

- Devletler, bölgesel ve uluslarararası sistem içinde "yegane" aktör değildir. Schmitter bu açıklama çerçevesinde sistem içinde devlet dışı aktörlerin de olduklarını belirterek çoğulcu yapıdan bahseder. Ayrıca dinamik bir entegrasyonun sağlanmasında devlet dış1 aktörlerin rolünün önem arz ettiğine işaret etmektedir (Schmitter, 2005:257).

- Kimlik veya ortak ideallerden farklı olarak çıkarlar, bütünleşme sürecinde önemli bir itici güçtür. Ancak bütünleşme süreci başladığından beri "çıkar" kavramının aynı kalmasından bahsetmek mümkün değildir. Zira aktörler deneyimleri etrafında pek çok şey öğrenirler ve bu noktada onların beklentileri de değişebilir. 
- İşlevler (fonksiyonlar) bütünleşmede önemli bir odak noktasıdır. İşlevsel alanların birbirinden ayrılması noktasında karşılıklı anlaşmaya dayalı işlerin ifa edilmesi ve ilerleme kaydedilmesi noktasında aktör sayısındaki artış nedeniyle bir anlaşmazlık yaşanabilir.

- Uluslarüstü yapıdan bahsederek, uluslarüstü aktörlerin artan bir birlik ruhu geliştirebileceklerini, düşünce ve planlarını bu sürece enjekte edebileceklerini vurgular.

- Bütünleşmeyle ilgili stratejiler bir noktada birleşebilirler ancak aynı değillerdir. Aktörlerin kurallar ve politikalarda hemfikir olmaları, onların hedeflerinin aynı olmasından değil sahip oldukları farklı beklentilerin örtüşmesindendir (Schmitter, 2005, 259-260).

Schmitter Neofonksiyonalizmin bu varsayımlarını Haas ve ondan etkilenen Neofonksiyonalistlerin çalışmalarından elde ettiğini belirtip, tüm bu varsayımların orjinal kökeninin, AKÇT içinde bulunacağı Avrupa bütünleşmesi deneyimi tarafından eşit ölçüde doğrulandığının ve yarar sağladığının söylenemeyeceğini de ifade etmiştir (Schmitter, 2005:260-261).

Schmitter bütünleşme sürecini anlatırken "karar döngüleri” kavramını ortaya koymaktadır. Karar döngüleri, başlangıç (inititiation), ateşleme (priming) ve dönüştürücü (transformative) olmak üzere üçlü bir sınıflandırmaya tabii tutulmuştur. Bu bağlamda başlangıç döngüsünde, AKÇT'den AET'ye giden süreç anlatılmaktadır. Ayrıca, müzakere içindeki ve çeşitli motivasyon ve beklentilere sahip tarafların bu döngüde yayılma stratejisini benimseyecekleri belirtilmiştir. Ateşleme döngüsünde, AET'nin kurulduğu, bölgesel konuların çok daha fazla oturduğu/kökleştiği, bölgesel çıkar teşekküllerinin katılımı, yoğunluğu ve kapsamının genişlediği ve farklı bölgesel kimliklerin geliştiği dönemleri ele almaktadır. Ayrıca söz konusu döngünün, kriz durumlarında olumlu etki yaparak bütünleşmeyi devam ettirmesi beklenmektedir. Dönüştürücü aşamada ise ekonomik bütünleşmeden siyasi bütünleşmeye doğru bir evrimin tam olarak gerçekleşmesi beklenmektedir (Schmitter, 1970:851-865).

Schmitter döngüler etrafında oluşturduğu söz konusu modelin varsayımlarını şu şekilde siralamaktadir:

- Bölgesel bürokratların rolünde bir artış olacaktır. Üstüne üstlük, bu aktörlerin bölgesel süreçleri etkilemedeki kapasiteleri artacaktır. Kendi etkilerinin resmi katılımcılar gibi tanınması konusunda 1srarcı olacaklardır.

- Yeni bölgesel süreç, yerel statü etkisine neden olacaktır. Bölgesel kurumların revize edilerek tanımlanmış düzeyi, yerel politikalar içindeki statüleri ve etkileri tanınmaya başlayacaktır. Bakanlıkların, siyasi partilerin, kurumların bölgesel karar vermede sahip oldukları kaynaklar diğer ulusal kurumları da teşvik edecektir.

- Ulusal aktörlerin doğasında önemli bir değişim olacaktır. Herhangi bir kriz durumunda bütünleştirici veya ayrıştırıcı stratejilerle tek bir birim olarak düşünüleceklerdir.

- Ulusal hükümet aktörleri, stratejileri birleştirirken baskın rollerini devam ettirebilirler fakat onlar alt ulusal gruplarla diğer hükümet aktörlerinin koalisyonu tarafindan da sinırlandırılabilirler.

- Bölgesel bürokratlar tarafindan güçlendirilen aktivizm, onların tam olarak aktör statüsü kazanma konusundaki teşebbüsleri, ulusal aktörlerin parçalanması ve 
farklılıkların oluşması, bütünleşme süreci içinde ateşleyici döngünün çok fazla tartışılmasına sebep olmaktadır (Schmitter, 1970:862-865).

\section{NEOFONKSIYYNALIZMIN KARAYIPLER TOPLULUĞU'NA YANSITILMASI}

Karayipler Topluluğu (Caricom) isimli bölgesel örgüt, 1973 yılında Chaguarmas Antlaşmasının Barbados, Guyana, Jamaika, Trinidad ve Tobago tarafından imzalanmasıyla kurulmuştur. Günümüzde 15 asil ve 5 ortak üyeye sahip olan söz konusu topluluk kurulmadan önce, Karayip bölgesindeki devletler, serbest ticaret alanı oluşturan Karayip Serbest Ticaret Birliği (Carifta) altında birleşmekteydiler $\left(\right.$ Caricom $_{a}$, 2017; Hey, 2003:34). Bu minvalden hareketle Caricom'un, Carifta'dan doğduğu/evrimleştiği görülmektedir.

Sağlık, ulaşım, eğitim gibi alanlarda da aktif olan, temel hedefleri arasında üçüncü devletlerle ekonomik ilişkiler geliştirmek ve üye devletler arasında dış ve ekonomi politikalarına yönelik eşgüdümün sağlanması bulunan ve kuruluşundaki hedefi ekonomik entegrasyonun sağlanması olan Caricom, (Caricomb süreci içerisine girmiştir. Bu bağlamda takip edilen politikalarla beraber söz konusu topluluk, Chaguarmas Antlaşması'nın 2001 yılında dokuz protokolün birleştirilerek revize edilmiş şekliyle Karayipler Topluluğu Tek Pazarı ve Ekonomik Birliği’ne (CSME) ${ }^{7}$ evrilmiştir. 1 Ocak 2006 tarihinde Barbados, Beliz, Guyana, Jamaika, Suriname, Trinidad ve Tobago'nun yer aldığı mevzubahis CSME mekanizmasının uygulama alanı 1 Temmuz 2006'da Antigua ve Barbuda, Dominik, Grenada, St. Kitts ve Nevis, St. Lucia ve St. Vincent ve Grenadinler'in katılımıyla 6 devletten 12 devlete genişlemiştir (Caribbean Elections, 2019). CSME mekanizmasının oluşturulmasındaki nihai amaç ise bölgeyi, küresel piyasalarla rekabet edebilir hale getirmektir.

Barışçıl bir entegrasyonun başarılması konusunda $\mathrm{AB}$, tüm bölgesel bütünleşme teşebbüsleri arasında en önemli ve geniş kapsamlı girişimdir (Malamud ve Schmitter, 2011:135). AB ekseninde yaşanan ilk bütünleşme çabalarında önem arz eden ve söz konusu bütünleşmenin teorize edilmesinde somut ve anlamlı bir başlangıç noktasını oluşturan Neofonksiyonalizm teorisi ekseninde ortaya konan çıktıların, Avrupa dışında bir coğrafyada bulunan Karayipler Topluluğu'na (Caricom) yansımasının analiz edilmesi, söz konusu teorinin dünyanın başka bölgelerinde model alınıp alınamayacağının incelenmesi bağlamında önem arz etmektedir. Bir diğer ifadeyle, bir bütün olarak Neofonksiyonalizm teorisi ve özelde söz konusu kuramın iki önemli teorisyeni olan Ernst Haas ve Philippe Schmiter'ın ortaya koyduğu çıktıların Caricom'a yansitılması, Neofonksiyonalizm teorisinin Avrupa dışında bir bölgedeki işlerliğinin test edilmesine olanak sağlamaktadır. Bu bağlamda, Neofonksiyonalizm teorisi ekseninde Caricom'daki bütünleşme süreci analiz edilirken, teorinin önemli çıktılarından olan yayılma etkisi, CSME mekanizması, ve supranasyonel bir kurumu teşkil eden Karayipler Adalet Divan1- (Caribbean Court of Justice-CCJ) ${ }^{8}$, karar döngüleri, dişsal faktörler ve doğal entropi hipotezi, siyasallaşma ve kamuoyu etkisi üzerinde durulacaktır.

David Mitrany’nin öncülüğünü yaptı̆̆ fonksiyonalizm teorisinden farklı olarak, nihai amacın siyasi bir toplumun yaratılması olan Neofonksiyonalizm, entegrasyonun teknik ve ekonomik

\footnotetext{
7 Çalışmada Karayipler Topluluğu Tek Pazarı ve Ekonomik Birliğine yönelik CSME kısaltması kullanılmaktadır.

${ }^{8}$ Çalışmada Karayipler Adalet Divanına yönelik CCJ kısaltması kullanılmaktadır.
} 
sektörde başlayarak, yayılma etkisiyle siyasi sektöre kayacağı üzerine temellenmektedir. Söz konusu yayılma etkisi ise belirtildiği üzere, temel olarak fonksiyonel ve siyasi olmakla birlikte işlenmiş ve coğrafi yayılmanın da dahil edilmesi zarfında ele alınmaktadır. $\mathrm{Bu}$ bağlamda yayılma etkisi Caricom'daki entegrasyon sürecini yansıtmaktadır. Nitekim, Coricom'un kuruluşundaki ilk amaç olan ekonomik sektörde bütünleşmenin, zaman içerisinde oluşturulan CSME mekanizması doğrultusunda derinleştiği ve söz konusu bütünleşmenin yayılma etkisi çerçevesinde göç, eğitim, sosyal güvenlik, çevre gibi alanlara ve bu alanlarda geliştirilen politikalara sıçradığı görülmektedir ki bu durum fonksiyonel yayılma etkisini ortaya koymaktadır. Bu hususu biraz daha ayrıntılandırmak gerekirse, ekonomik entegrasyonun kalbi konumunda bulunan CSME mekanizması ile şu hedefler söz konusudur:

1- Mal ve hizmetlerin serbest dolaşımı,

2- Şirket kurma hakk1,

3- Ortak dış tarifeler üzerinde anlaşma

4- Sermayenin serbest dolaşımı

5- Ortak ticaret politikas1

6- Kişilerin serbest dolaşımı

7- Yasaların uyumlaştırılması (Caribean Elections, 2019).

Dolayısıyla Caricom'un dayandığı dört temel hedeften biri olan ekonomik entegrasyon, CSME mekanizmasıyla ilişkilendirilmektedir. Ancak diğer sac ayakları olan insani ve sosyal kalkınma, dış politika koordinasyonunun sağlanması ve güvenlik alanında işbirliğinin kurulması hedefleriyle ilgili hükümlerin CSME mekanizması içerisinde yer alması çerçevesinde mevzubahis mekanizma diğer hedefleri de içerisinde barındırmaktadır (Ministry of Foreign and Caricom Affairs, 2018). Bununla beraber serbest dolaşımın sağlanması konusunda göçmenlik prosedürlerinin uyumlaştırılması, Coricom vatandaşlarının seyahat engellerinin kaldırılması için sosyal güvenlikle ilişkili hükümlerin CSME mekanizması içerisinde yer alması, bölge içi ürünler üzerinde tarife ve kotaların kaldırılmasında sağlık ve güvenlik standartlarının uyumlaştırılması da fonksiyonel yayılma etkisini örneklendirmektedir. Öte yandan, Chaguarmas Antlaşmasının revize edilmiş haliyle yeni kurumların oluşturulduğu görülmektedir. Bu noktada Neofonksiyonalizm teorisinin siyasi yayılma etkisinin ön plana çıktığı görülmektedir. Siyasi yayılma etkisi bağlamında önem arz eden husus ise supranasyonel bir kurum olan Karayipler Adalet Divanı'nın (Caribbean Court of Justice-CCJ) kurulmasıdır. Bir diğer ifadeyle, Caricom üye devletlerinin ekonomik, sosyal ve siyasi değişimleriyle bölgesel entegrasyondaki yayılmayı yansıtan revize edilmiş antlaşma ile supranasyonel kurumların kurulması ve bir sektörde başlayan bütünleşme kararın diğer sektörlere yayılması (CCJ ve CSME mekanizması) Caricom'daki fonksiyonel ve siyasi yayılmaya işaret etmektedir. Diğer taraftan supranasyonel kurumların belirleyiciliğini ortaya koyan siyasi yayılma etkisi, CCJ'nin hükümlerinde de gözlemlenmektedir. Örneğin, CCJ'nin mülkiyetle ilgili almış olduğu karar, Barbados yönetiminin sivil prosedürel kuralları belirleme noktasında kendi yasal sistemini güncellemesine neden olmuştur. Bu noktada supranasyonel bir kurum olan CCJ, hem revize edilmiş antlaşmanın yorumlanmasında nihai yetki sahibidir hem de asli yarg1 yetkisine ek olarak temyiz mahkemelerinin yarg1 yetkisine de sahiptir. CCJ'nin temyiz mahkemesi yargı yetkisi altında üye devletlerin var olan yasal yapılarının gözden geçirilmesi ve kanunlarını doğrudan etkileyebilme gücü bulunmaktayken üye devletlerin ticaret ve gümrük ile ilişkili düzenlemelerinde CCJ, asli yargı yetkisine sahiptir 
(Ministry of Foreign and Coricom Affairs, 2018). CCJ'nin sahip olduğu bu yetkiler ise ona devletlerin üzerinde bir güç/yetki vermektedir. Tüm bu hususlara ek olarak, yukarıda belirtildiği gibi CSME mekanizmasının altı devletten on iki devleti kapsayacak şekilde genişlemesi ise Neofonksiyonel teorinin ortaya koyduğu coğrafi yayılma etkisi ile bir nevi örtüşen bir hususu teşkil etmektedir.

Öte yandan, 2008 yılında Caricom ve Avrupa Birliği arasında imzalanan Ekonomik Ortaklık Anlaşması -Economic Partnership Agreement (EPA)-,CSME mekanizmasının oluşturulması ve CCJ'nin kurulması sonrasında Caricom'daki kurumsallaşmaya ve entegrasyona ilişkin hayata geçirilmeye çalışılan etkin yapılanma sürecindeki bir diğer önemli adımı teşkil etmektedir. Söz konusu anlaşma ekseninde şu hususlar üzerinde anlaşma sağlanmıştır:

1- İki bölgenin/birliğin birbirleriyle yatırım ve ticaret yapmaları olanaklı hale getirilmiş,

2- Caricom üye devletleri için AB pazarına öngörülebilir ölçüde erişim sağlanmış,

3- $\mathrm{AB}$, Caricom devletlerine hizmet sektörünü kademeli olarak açmayı öngörmüş,

4- $\mathrm{AB}$, Caricom devletlerine gümrüksüz kota içermeyen pazardaki tüm ürünlere erişim sağlamıştır (European Commission, 2019).

İki devlet arasında ikili anlaşmaları ve bir grup devlet arasında çok taraflı anlaşmaları kapsayarak Caricom ve AB arasında yeni bir denge kurulmasına sebebiyet veren söz konusu anlaşma, bölgesel ittifak ve ticaret ortaklığında önem arz etmektedir. Caricom ve $A B$ arasında imzalanan mevzubahis anlaşmanın Neofonksiyonalizm kuramı çerçevesinde analizinde ise Philippe Schmitter'ın ortaya koyduğu "karar döngüleri (decision cycles)" devreye girmektedir. Nitekim Schmitter'ın ele aldığı karar döngüleri, Caricom'daki entegrasyon teşebbüsü ve bunun derinleşeceğini göstermektedir. Bu bağlamda söz konusu karar döngüleri, Caricom'daki devletlerin Ekonomik Ortaklık Anlaşması üzerinden neden AB ile müzakere kararı aldıklarını göstermektedir. Bununla beraber, CSME mekanizmasının oluşturulması teşebbüsü de karar döngüsü modeline işaret etmektedir. Nitekim Caricom'un kuruluşunda orijinal metni oluşturan Chaguarmas Antlaşması ile kurumların ve bütünleşmenin sınırları belirlenmiştir. Söz konusu antlaşmanın revize edilmiş haliyle ise Caricom' daki bütünleşme derinleşmiş, var olan kurumlara yeni yetkiler tesis edilmiş, gümrük düzenlemeleri, güvenlik standartlarına yönelik düzenlemeler gibi spesifik alanlarda devletlerin yetkileri bölgesel organlara devredilmiş, supranasyonel kurumlar oluşturulmuş ve Caricom'un kurulmasındaki nihai hedef yeniden tanımlanarak genişletilmiştir (Treaty Of Chaguaramas, 1973; Revised Treaty of Chaguaramas, 2001). Bu bağlamda revize edilmiş antlaşma, karar döngüleri bağlamında Schmitter tarafından ortaya konan ilk aşamayı ( ${ }^{9}$ başlangıç aşamasını -initiation-) teşkil etmektedir. Diğer taraftan, Caricom ve AB arasında imzalanan Ekonomik Ortaklık Anlaşması'nın müzakeresinde devlet dışı aktörlerin etkisi bulunmaktadır. Bu haliyle anlaşma, kurumların ve siyasi elitlerin ${ }^{10}$ insiyatifini yansıtmaktadır. Öyle ki şuanki ismi Ticaret Müzakereleri Ofisi ${ }^{11}$ (Caricom Office of Trade Negotiations-OTN) olan, revize edilen

\footnotetext{
${ }^{9} \mathrm{Bu}$ aşama Avrupa bağlamında AKÇT'dan AET'na giden süreci ele alırken, Caricom ekseninde Chaguarmas Antlaşması'nın ortaya koyduğu yapının, antlaşmanın revize edilmiş haliyle dönüşüm geçirmesini yansitmaktadır.

${ }^{10}$ Siyasi elitler EPA’nın işlerliği ve koşullarına ilişkin karar vermiştir. Bu durum, Caricom'daki bölgesel entegrasyon seviyesi (aktörlerin karar verme kapasitesi) ve konu alanlarının kapsamına işaret etmektedir ki mevzubahis seviye ve alan yaklaşımı Schmitter'ın aktör stratejileri yaklaşımı içerisinde ortaya konmaktadır.

${ }^{11}$ Ticaret Müzakereleri Ofisi, uzman bireylerin, üye devletlerin ticaretli ilişkili diplomatları, bölgesel uzmanlar, üye devletlerin ilgili bakan ve bakan yardımcılarının yer aldığı "Teknik Çalışma Gruplarından” oluşmaktadır.
} 
Chaguaramas Antlaşmasıyla oluşturulan ve bölgenin yer aldığ1 çeşitli ticari müzakerelerde, müzakere stratejilerinin koordine edilmesi ve geliştirilmesinde rol oynayan Karayip Bölgesel Müzakere Sistemi'nin (The Caribbean Regional Negotiation Machinery-CRNM) mevzubahis anlaşmanın imzalanması sürecindeki müzakerelerde katkısı söz konusu olmuştur (Lewis-Ambrose, 2013:35-36). Bu noktada, hem Caricom ve Avrupa Birliği arasında Ekonomik Ortaklık Anlaşması'nın imzalanmasında devlet dışı bir aktörün de rolünün bulunması -CRNM mekanizması- hem de revize edilmiş Chaguaramas Antlaşması ile oluşturulan CSME mekanizması ve supranasyonel bir kurum olan CCJ'nin kurulması Schmitter'ın karar döngüleri içerisindeki ateşleme döngüsünü (priming cycle) göstermektedir. Diğer taraftan, Neofonksiyonalizm teorisinin ortaya koyduğu bölgesel bütünleşmede dişsal faktörlerin etkisini yansıtan "dişsal faktörler" hipotezi, Caricom ile AB arasında imzalanan Ekonomik Ortaklık Anlaşması'nın imzalanma sürecindeki dişsal bir faktör olan Dünya Ticaret Örgütü'ne (DTÖ) işaret etmektedir. Nitekim DTÖ'nin kararları, Caricom devletlerini AB'nin hedefleri, yapısı ve kuralları altında bir anlaşma yapmaya zorlamıştır (Economic Commission of Latin America and Caribbean, 2008). Ayrica devletlerin (topluluğa ve/veya birliğe üye devletlerin) ortak müzakerelerini küresel bağlamdan izole etme teşebbüşlerinin büyük zorluklara yol açacağına işaret eden Neofonksiyonalizmin dışsallaşma hipotezi, Caricom ve $A B$ arasındaki ortaklık anlaşmasının imzalanması sürecinde belirleyici bir unsur olmuştur.

Ekonomik Ortaklık Anlaşması sürecinde Caricom'daki siyasallaşma süreci,-ortak karar alma süreçlerinde tartışmaların ve uyuşmazlıkların yaşanması- Neofonksiyonel teorinin ortaya koyduğu bir diğer varsayıma işaret etmektedir. Nitekim anlaşma müzakerelerinin ilk iki aşaması, teknik ve oldukça karmaşık olmasına rağmen herhangi bir uyuşmazlığa ya da eleştirel görüşlere maruz kalmamış ve anlaşmanın taslak metni üzerinde uzlaşıya varılmışken, son iki aşamada Caricom üye devletleri ve sivil toplum grupları arasında ciddi boyutta anlaşmazlıklar yaşanmıştır (Girvan, 2011:92). Öte yandan, bu süreçte yaşanan pazarlıklar ve Caricom'un Avrupa Komisyonu ile yapılacak müzakerelerde kurumsal bir düzenleme olarak Afrika Karayipler ve Pasifik Devletleri Grubu Forumu'nu -Cariforum- kurmaya zorlanmas1 dışsal etkiye ve dolayısıyla Neofonksiyonalizmin doğal entropi hipotezine örnek teşkil etmektedir. Adaptosyonu da önceliklendiren mevzubahis hipoteze bir diğer örnek ise Caricom içerisinde tek pazarın uygulanmasına dönük adaptasyonun oluşmasıdır.

Tüm bu hususlara ek olarak, Neofonksiyonalizmin Caricom'a yansitılmasında ele alınması gereken bir diğer husus, teorinin kendi içinde taşıdığ 1 durumla ilişkilidir ki ilgili kısımda belirtildiği gibi teori, kendisinin sadece Avrupa bazında değil, söz konusu coğrafya dışında da kullanılabilirliğini test etme yaklaşımını kendi içinde bulundurmaktadır. Schmitter'ın da ortaya koyduğu haliyle (2004) teori, analiz süreci bağlamında önemli bir başlangıç noktasını teşkil etmektedir (Niemann, Lefkofridi ve Schmitter, 2018:13).

Sonuç olarak, bir bütün olarak Neofonkisyonalizm teorisinin ve iki önemli teorisyenin -Ernst B. Haas ve Philippe Schmitter- ortaya koyduğu varsayımların Avrupa dışında bir coğrafyada bulunan Caricom'a tam anlamıyla, somut ve değişmez bir biçimde yansımadığı ancak analiz edildiği gibi teorinin birçok önemli çıktısının Caricom bağlamında işlerlik kazandığı görülmektedir. 


\section{SONUÇ}

Avrupa'da birleşme/bütünleşme fikrinin tarihsel kökeni çok eskiye -Eski Yunan'a- dayansa da söz konusu coğrafyada somut anlamda entegrasyon girişiminin başlangıcı ve dolayısıyla bütünleşmeye yönelik fikirsel düzlemin pratik boyuta taşınması II. Dünya Savaşı sonrasıdır. II. Dünya savaşından düzen kurucu muzaffer güçlerden biri olarak çıkan ABD’nin, yeni bir düzen yaratmaya çalışması bağlamında savaşın hezimeti doğrultusunda sosyal, siyasi, askeri ve psikolojik olarak kırılmalar ve yıkım yaşayan Batı Avrupa yeniden ayağa kalkmaya başlamıştır. Öte yandan Fransız Dışişleri Bakanı Robert Schuman ve önemli siyasetçi Jean Monnet tarafından hazırlanıp 9 Mayıs 1950'de açıklanan Schuman Bildirisi, Avrupa entegrasyonunda çok önemli bir diğer adımı teşkil etmiştir. Her ne kadar günümüz itibariyle içerisinde pek çok problemi taşısa da ve entegrasyon zarfinda nihai hedef olan siyasi bütünleşme henüz tam anlamıyla hayata geçirilemese de ekonomik entegrasyondan siyasi entegrasyona evirilme amacıyla yola çıkan ve başarıya ulaşan derinleşme, genişleme süreçlerine haiz olan Avrupa bütünleşmesi, geçirdiği değişim ve dönüşüm itibariyle takdire şayandir.

Avrupa bütünleşme sürecini en iyi şekilde açıklayan, somut anlamda bütünleşme girişimlerinin teorik bir zemine inşa edilmesi noktasında ortaya çıan ve uluslararası bütünleşme teorileri arasında yer alan Neofonksiyonalizm, ekonomik ve siyasi bütünleşme aşamaları arasında bağ kuran bir teoridir. Neofonksiyonalizmin Avrupa bütünleşme sürecini en iyi şekilde açıklayan teori olarak düşünülmesinin ardında, açıklamaya çalıştığı Avrupa entegrasyonunun büyük oranda başarıya ulaşarak diğer bütünleşme teorilerinden öncelikli olması bulunmaktadır. Öte yandan, supranasyonel ve hükümetlerarası özelliklere haiz olarak nev-i şahsına münhasır bir yapı olan AB'nin bütünleşme serüveninin teorize edilmesi, David Puchala'nın belirttiği gibi "bir körün bir fili tanımlaması" girişimine benzemektedir (Puchala, 1971:267). Nitekim her bir bütünleşme teorisi, söz konusu sürece farklı açılardan yaklaşmaktadır. Bu bağlamda Wiener ve Diez'in de vurguladığı şekliyle farklı kuramlar, Avrupa entegrasyon kuramları mozaiğine bir taş daha eklemektedir. Ancak hiç bir yaklaşım birbiri ile doğrudan kıyaslanamayacağı gibi birbiriyle de örtüşmez değildir (Wiener ve Diez, 2009:19). Bu minvalde hareketle, fonksiyonalizm ve transaksiyonalizm teorilerinin baz1 özelliklerini içinde barındırarak eklektik bir model sunan Neofonksiyonalizm, Avrupa bütünleşmesi sürecinin son aşaması olarak görülen siyasi bir topluma ulaşma hedefi doğrultusunda bütünleşmenin öncelikle ekonomik alanda sağlanması gerektiğini vurgulamaktadır. Neofonksiyonalistler tarihsel bir perspektiften bakarak, devletlerin siyasal alanda yetkilerini devretmekten kaçındıkları tespitiyle, bütünleşmenin ekonomik alanda başlayıp aşamalı bir şekilde siyasi bütünleşmeye evrilmesi gerektiğini ifade etmektedir.

Çalışmada Neofonksiyonel teorinin fikir babası olarak kabul gören Ernst B. Haas ve bu teoriye önemli katkılar sunan Philippe Schmitter'1n teoriye yönelik ne gibi katkılarda bulundukları karşılaştırmalı bir profilden ele alınmıştır. Bu bağlamda denilebilir ki Ernst Haas'ın özellikle yayılma etkisi, firmaların, şirketlerin günlük hayat düzeyinde yayılması ve kurumsallaşması çerçevesinde bölgesel entegrasyonla uzun dönemli bir bütünleşme sağlanabilir saptaması ve Philippe Schmitter'ın aktör stratejileri ve karar döngüleri kavramlarını geliştirmesi hem teoriye yapılan katkı açısından hem de Avrupa bütünleşme sürecinin zihinlerde daha da anlamlandırılması bakımından önem arz etmektedir. 
Schmitter, Neofonksiyonalizmin diğer bütünleşme teorilerine bir alternatif olmaktansa çok kompleks bir süreci açıklamaya çalıştığını ifade ederken, Haas'ın vurgulamaya çalıştı̆̆ Batı Avrupa'nın entegrasyonudur. Bir başka ifadeyle benzer ekonomik gelişmişlik düzeyi ve mantaliteye sahip ülkeleri entegre etmektir. Öte yandan, her ne kadar yaşanan söz konusu süreç Fransa'nın yeniden emperyal güç olma yolunda ilerlemesi ve işin içine milliyetçiliği dahil etmesi noktasında Haas'ın hayal kırıklığına uğramasına sebep olsa da kendisi tarafından ortaya konulan yeni çalışmalar bağlamında teori güncellenmeye çalışılmıştır.

Ana odak noktası ve nihai amacı Avrupa bütünleşme sürecinin -özellikle ilk aşama olan 1950'ler ve derinleşmenin görülmeye başladığı 1960'lar arası dönem- teorize edilmesinde önemli bir başlangıç noktasını teşkil eden Neofonksiyonalizm teorisinin ve kuramın iki önemli teorisyeni olan Ernst B. Haas ve Philippe Schmitter'ın ortaya koyduğu varsayımların Karayipler Topluluğu (Caricom) üzerindeki yansımalarının işlerliğini test etmeye çalışan bu çalışma ekseninde, söz konusu hipotezlerin Caricom' daki bütünleşme sürecine tam anlamıyla, bütünleşik ve değişmez bir biçimde yansımadığı fakat teorinin ortaya koyduğu birçok önemli varsayımın Caricom'daki mevzubahis entegrasyon süreciyle uyumluluk gösterdiği sonucuna varılmaktadır. Bu bağlamda teorinin önemli hipotezlerinden olan yayılma etkisi (fonksiyonel, siyasi ve coğrafi yayılma), supranasyonalizm, dişsal faktörler ve doğal entropi hipotezi, devlet diş1 aktörler ve siyasi elitlerin etkisi, siyasallaşma ve kamuoyu etkisi ve karar döngülerinin (özellikle başlangıç ve ateşleme döngüsü) Caricom'daki entegrasyon sürecinde belirleyici olduğu ve bu noktada Neofonksiyonalizmin önemli varsayımların söz konusu bütünleşme sürecine yansıdığı görülmektedir.

\section{KAYNAKÇA}

Arı, T. (2010). Uluslararasu Iliş̧kiler Teorileri: Çatışma, Hegemonya, İşbirliği, Bursa:MKM Yayınc1lik.

Barrera, M. ve Haas, E. (1969). "The Operationalization of Some Variables Related to Regional Integration: A Research Note", International Organization, C.23 S.1, ss. 150-160.

Bergmann, J. ve Niemann, A. (2013). "Theories of European Integration and their Contribution to the Study of European Foreign Policy", https://pdfs.semanticscholar.org/3a92/c6ba0f6223d86d561b619aae0e5d7401007c.pdf, (09.07.2019).

Caribean Elections. (2019). "CARICOM Single Market and Economy (CSME)", http://www.caribbeanelections.com/education/integration/csme.asp, (03.10.2019).

Caricom $_{\mathrm{a}}$ Caribbean Community Secretariat. (2017). http://www.caricom.org, (15.09.2019).

Caricom $_{\mathrm{b}} \quad$ Caribbean Community Secretariat.

(2017). http://caricom.org/community/objectives/, (15.09.2019).

Economic Commission of Latin America and Caribbean. (2008). "Review of CARIFORUMEU-EPA in Development Cooperation and WTO Compatability", https://www.cepal.org/en/publications/38708-review-cariforum-eu-epa-developmentcooperation-and-wto-compatability, (03.09.2019). 
Eilstrupp-Sangiovanni, M. (2006). Debates on European Integration, Houndmills: Palgrave.

Etzioni, A. (1962). “A Paradigm for the Study of Political Unification”, World Politics, C.15, S.1, ss. 44-74.

European Commission. (2019). “Caribbean”, https://ec.europa.eu/trade/policy/countries-andregions/regions/caribbean/, (22.09.2019).

Faber, A. (2010), “ The Further Development of Neofunctionalism Until the Early 1970s”, https://www.kuwi.europauni.de/de/lehrstuhl/vs/politik2/lehre/lehrarchiv/WS1011/integration_theories/Stumpf_ Presentation_The_further_development_of_Neofunctionalism.pdf, (21.09.2019).

Gehrels, F. (1960). “ The Uniting of Europe: Political, Social and Economic Forces, 19501957 by Ernst B. Haas”, Journal of Political Economy, C.68, S.2, ss. 196-197.

Girvan, N. (2011). " Technification, Sweetification,Treatyfiction:Politics of the CaribbeanEU Economic Partnership Agreement”, Shalini Puri (Edt.), The Legacy of Caribbean Radical Politics, NewYork: Taylor and Francis, ss. 90-101.

Haas, E. (1958). The Uniting of Europe: Political, Aocial and Economical Forces 1950-1957, London: Stevens \& Sons Limited.

Haas, E. (1961). "International Integration: The European and the Universal Process." International Organization, C.15, S.3, ss. 366-392.

Haas, E. (1964). "Technocracy, Pluralism and New Europe", S. Graubard (Edt.) A New Europe?, Boston: MA, ss. 62-88.

Haas, E. (1970). Beyond the Nation State, Stanford: Standford University Press.

Haas, E. (1975). The Obsolescence of Regional Integration Theory, California:University of California.

Haas, E. ve Schmitter, P. (1964). “ Economics and Differential Patterns of Political Integration:Projections About Unity in Latin America", International Organization, ss.705-737.

Hey, J.K., (2003), Small States in World Politics, Boulder: Lynne Rienner Publishers.

Kahraman, S. (2014). “Avrupa Bütünleşmesi Kuramları:1950-1970 Yılları”, Belgin Akçay ve İlke Göçmen (Edt.), Avrupa Birliği: Tarihçe, Teoriler, Kurumlar ve Politikalar, Ankara:Seçkin Yayıncılık, ss. 71-85.

Lewis-Ambrose, D. (2013). Moving from Intancy to Young Adulthood: A Contemporary Review of the Development of the Virgin Islands, Cambridge Scholars Publishing.

Lindberg, L. N. (1963). The Political Dynamics of European Economic Integration, London: Stanford University Press.

Mason, L. (1959). “The Process of Integration: A Critique of Four Recent Books on European Unification", The Journal Conflict Resolution, C.3, S.2 ss. 172-181. 
Mattli, W. (2005). "Ernst Haas's Evolving Thinking on Comparative Regional Integration: Of Virtues and Infelicities", Journal of Public Policy, C.12, S.2, ss. 327-348.

Mercan, S. (2011). “ Siyasal Bütünleşme Kuramları Işı̆̆ında AB Genişlemesi”, Ankara Avrupa Çalışmaları Dergisi, C.10, S.1, ss. 67-83.

Ministry of Foreign and Caricom Affairs. (2018). "The 18th Special Meeting of Heads of Government of CARICOM on the CARICOM Single Market and Economy (CSME)",https://foreign.gov.tt/resources/news/statement-sen-hon-paula-gopee-scoong-minister-foreign-caricom-affairs-media-conference-regarding-trinidad-and-tobagoshosting-18th-special-meeting-heads-government-caricom-caricom-single-market-andeconomy-csme/, (22.09.2019).

Moravsick, A. (2005). 'The European Constitutional Comprise and the Neofunctionalist Legacy", Journal of European Public Policy, C.12, S.2, ss. 349-386.

Niemann, A. (2016), "Theorising Internal Security Cooperation in the European Union: A Neofunctionalist Perspective", https://www.researchgate.net/publication/330412606_Theorising_Internal_Security_C ooperation_in_the_European_Union_A_Neofunctionalist_Perspective (19.10.2019).

Niemann, A. Lefkofridi, Z. ve Schmitter, P. (2018). "Neofunctionalism", https://www.researchgate.net/publication/330494709_3_Neofunctionalism, (20.09.2019).

Özen, Ç. (1998). Türkiye-Avrupa Birliği İlişkilerinin Neofonksiyonalist Teori Çerçevesinde Analizi, Gazi Üniversitesi Sosyal Bilimler Enstitüsü Yayınlanmış Master Tezi, Ankara.

Preston, C. (1997). Enlargement and Integration in the European Union, London:Routledge.

Puchala, D. (1971). "Of Blind Men and International Integration", Journal of Common Market Studies, C.10, S.3, ss. 267-284.

Revised Treaty of Chaguaramas. (2001). https://caricom.org/documents/4906-revised_treatytext.pdf, (25.09.2019).

Rosamond, B. (2005). "The Uniting Europe and the Foundation of EU Studies:Revisiting the Neofunctionalism of Ernst B. Haas", Journal of European Public Policy, C.12, S.2, ss. 237-254.

Schmitter, P. (1969). 'Three Neo-Functional Hypotheses about International Integration, International Organization, C.23, S.1, ss. 161-166.

Schmitter, P. (1970). "A Revised Theory of Regional Integration", International Organization, C.24, S.4, ss. 836-868.

Schmitter, P. (2004). “ Neo-Neo Functionalism”, European Integration Theory, Oxford: Oxford University Press, ss. 45-74.

Schmitter, P. (2005). "Ernst B. Haas and the Legacy of Neofunctionalism", Journal of European Public Policy, C.12. S.2 ss. 255-272. 
Schmitter, P. ve Letkofridi, Z. (2016). "Neo-Functionalism as a Theory of Disintegration", https://cadmus.eui.eu/bitstream/handle/1814/40332/Schmitter_Lefkofridi_2016.pdf?se quence $=2,(16.08 .2019)$.

Toprak, E. (2007). "Neofonksiyonalizmden Yapısalcılığa, Entegrasyon Kuramları Işığında Türkiye-Avrupa Birliği Uyumu”, Ankara Avrupa Çalışma Dergisi, C.7. S.1, ss. 69-89.

Tranholm-Mikkelsen, J. (1991). “ Neo-Functionalism:Obstinate or Obsolete?A Reappraisal in Light of the New Dynamism of the EC", Millennium:Journal of International Studies, C.20, S.1, ss. 1-21.

Treaty of Chaguaramas. (1973). https://caricom.org/about-caricom/who-we-are/ourgovernance/the-original-treaty/, (01.09.2019).

Weiner, A. ve Diez, T. (2009). “Introducing the Mosaic of International Theory”, Antje Wiener ve Thomas Diez (Edt.), European Integration Theory, UK:Oxford University Press, ss. 1-24.

Yapıc1, M. ( 2007). “ Uluslararası İlişkiler Disiplininde Entegrasyon Teorilerinin Yeri ve Etkinliği”, Dokuz Eylül Üniversitesi Sosyal Bilimler Enstitüsü Dergisi, C.9. S.3, ss. 130-157. 